\title{
ALIH FUNGSI LAHAN PERTANIAN DAN DAMPAKNYA TERHADAP KEHIDUPAN PENDUDUK DI KECAMATAN SAYUNG KABUPATEN DEMAK
}

\section{(Changes In Agricultural Land Use And Its Impacts On The Lives Of Farmers At Sayung Subdistrict, Demak Regency)}

\author{
R. Janah, B. T. Eddy dan T. Dalmiyatun \\ Program Studi S1 Agribisnis Fakultas Peternakan dan Pertanian \\ Universitas Diponegoro, Kampus Tembalang - Semarang 50275 \\ Email: rifatuljanah@gmail.com \\ Diterima 13 Februari 2017, disetujui 1 Maret 2017
}

\section{ABSTRAK}

Penelitian ini bertujuan untuk mengetahui: 1) Perubahan fungsi lahan pertanian, 2) Dampaknya alih fungsi lahan terhadap kehidupan pendudukyang meliputi luas kepemilikan lahan, alih pekerjaan dan persediaan pangan pokok dalam keluarga. Penelitian ini dilaksanakan pada Desember 2016 sampai Januari 2017 di Kecamatan Sayung. Sayung dipilih sebagai lokasi penelitian karena 1) cukup tinggi mengalami alih fungsi lahan, 2) merupakan wilayah pertumbuhan industri dan perumahan karena berbatasan dengan Kota Semarang. Metode penelitian yang digunakan adalah survei. Data penjualan lahan diperoleh dari arsip 4 desa terpilih. Setiap desa diambil 20 responden yang terdiri dari 2 orang setiap tahun selama 10 tahun terakhir sehingga total responden 80 orang. Hasil penelitian menunjukkan bahwa di Kabupaten Demak terjadi peningkatan pengajuan perizinan alih fungsi lahan. Penurunan luasan lahan pertanian dari 2.136 ha menjadi 1.417 ha, turun dengan laju rata-rata $12,4 \%$ per tahun yang disebabkan oleh alih fungsi lahan. Faktor - faktor yang mempengaruhi alih fungsi lahan pertanian di Kecamatan Sayung berturut-turut adalah kebutuhan ekonomi (41\%), ibadah haji $(16 \%)$, usaha $(11 \%)$, pengobatan $(9 \%)$, pembayaran hutang $(8 \%)$, renovasi rumah $(4 \%)$, pembelian motor $(4 \%)$, pembagian warisan (4\%) dan tukar tambah lahan $(3 \%)$. Alih fungsi lahan sangat signifikan mempengaruhi jumlah penduduk yang mempunyai lahan pertanian, luas kepemilikan lahan, alih pekerjaan dan persediaan pangan keluarga.

Kata Kunci : alih fungsi, lahan, luas kepemilikan, alih pekerjaan, persediaan pangan

\section{ABSTRACT}

This study aimed to determine: 1) Changes in agricultural land use, 2) conversion of agricultural land and its impacts on the lives of the farmers covering land holdings, changes on occupations and supplies of staple food in the family. The research was conducted in December 2016 to January 2017 in the Subdistrict Sayung. Sayung is one of the subdistricts in Demak that 1) high enough experienced conversion of the land, 2) is an industrial and residential growth area because it borders the city of Semarang. The research method used was survey. Data on the sale of land was obtained from the archives of four selected villages. From each village was selected by 20 respondents consisting of two people each year for the last 10 years, bringing the 
total respondents 80 people. These results indicate that in Demak has been an increased on demand for land conversion permits and a decline in agricultural land area in subdistrict Sayung caused by land conversion. Factors that influence the conversion of agricultural land in the subdistrict of Sayung respectively were economic needs, debt service, Hajj, treatment, venture capital, home renovation, purchase of motorcycles, trade-ins of land and inheritance. The changes in land use significantly affected the number of people who have agricultural land, the amount of land ownership, the structure of employment and family food supply.

Keywords: Agriculture, land use, structure of employment, food supply

\section{PENDAHULUAN}

Alih fungsi lahan pertanian merupakan proses pengalihan fungsi lahan pertanian dari penggunaan untuk pertanian kepenggunaan lainnya, pada sebagian atau keseluruhan kawasan lahan yang umumnya mempunyai dampak negatif terhadap lingkungan maupun pada potensi lahan tersebut. Pada umumnya laju alih fungsi lahan dikaitkan dengan laju pertumbuhan penduduk yang mengakibatkan meningkatnya pemenuhan kebutuhan yang berbasis pada penggunaan lahan, seperti pemukiman dan fasilitas umum lainnya.

Proses alih fungsi lahan tidak dapat dihindarkan pada setiap wilayah yang sedang berkembang. Wilayah yang sedang berkembang biasanya mempunyai pertumbuhan penduduk yang cukup tinggi, kemudian diikuti dengan meningkatnya kebutuhan lahan untuk pemukiman dan fasilitas umum lainnya termasuk untuk industri. Proses alih fungsi lahan biasanya diawali dengan pelepasan lahan terutama karena proses penjualan lahan. Di samping itu, faktor pertumbuhan kawasan yang mendorong kenaikan harga lahan juga dapat memicu pelepasan lahan tersebut. Secara umum, alih fungsi lahan pertanian dari petani dipengaruhi oleh tiga hal. Pertama, faktor eksternal berupa dinamika pertumbuhan kawasan, demografi dan ekonomi. Kedua, faktor internal berupa kondisi sosial-ekonomi keluarga pengguna lahan. Ketiga, faktor kebijakan, berupa aturan dan perundangan serta pelaksanaan aturan tersebut.

Alih fungsi lahan juga dapat berperan sebagai penyebab terjadinya proses-proses sosial ekonomi yang lain. Secara makro, berubahnya fungsi lahan tersebut akan mengurangi luasan lahan pertanian yang dapat menjadi penyebab berkurangnya produksi pangan. Alih fungsi lahan yang tidak direncanakan dengan baik juga akan mengganggu keseimbangan ekosistem yang dapat menyebabkan terjadinya bencana, misalnya banjir dan tanah longsor. Secara mikro, pada tingkat rumah tangga, alih fungsi lahan dapat menjadi penyebab terjadinya berkurangnya kepemilikan lahan, berkurangnya persediaan pangan dan perubahan struktur pekerjaan.

Penelitian ini bertujuan untuk mengetahui pelepasan lahan dari keluarga selama 10 tahun terakhir, serta dampaknya terhadap kehidupan penduduk yang meliputi luas kepemilikan lahan, alih pekerjaan dan persediaan pangan dalam keluarga di Kecamatan Sayung Kabupaten Demak. Manfaat penelitian ini adalah sebagai referensi tentang alih fungsi lahan terutama bagi pemerintah dan perencana dalam menyusun kebijakan lahan.

\section{METODE PENELITIAN}

Penelitian alih fungsi lahan pertanian ini menggunakan metode penelitian survei. Metode survei menjelaskan dampaknya terhadap kehidupan penduduk dengan menyelidiki gejala yang telah terjadi untuk mendapatkan kebenaran dalam penelitian (Idrus, 2009). Metode survai mengambil sampel dari suatu populasi dan menggunakan kuesioner. Kuesioner merupakan alat mengumpulkan informasi dengan menyam- 
paikan sejumlah pertanyaan tertulis yang dijawab oleh responden (Nawawi, 2012).

Penelitian dilakukan bulan Desember 2016 - Januari 2017 di Kecamatan Sayung Kabupaten Demak. Pemilihan lokasi menggunakan pertimbangan keberadaannya yang berbatasan dengan kawasan industri Kota Semarang sehingga Kecamatan Sayung mengalami alih fungsi lahan yang intensif.

Pengumpulan data penelitian ini menggunakan kuesioner terstruktur yang diisi dengan wawancara untuk mendapatkan informasi yang berkaitan dengan alih fungsi lahan pertanian pada penduduk yang menjual lahan pertanian dalam waktu 10 tahun terakhir. Data sekunder pendukung diperoleh dari kantor Kecamatan Sayung, BPS Kabupaten Demak, BPN, Dinas Pertanian dan kantor desa.

Penentuan responden ditetapkan sebagai berikut: 1) Memilih empat desa yang terpadat penduduknya. Desa-desa terpilih adalah Desa Jetaksari, Desa Kalisari, Desa Karangasem dan Desa Dombo, 2) Mencari data penjualan lahan di kelurahan 10 tahun terakhir, 3) menentukan responden dengan melihat penjualan tanah terluas yang resmi dicatat di kantor desa. Setiap tahun diambil 2 responden sehingga untuk 4 desa terpilih 80 responden.

Data yang terkumpul dianalisis menggunakan statistik deskriptif kuantitatif nonparametrik dengan uji tabulasi silang (crosstab). Metode analisis statistik deskriptif adalah metode penelitian untuk menganalisis data dengan mendeskripsikan, menggambarkan secara faktual dan akurat mengenai fakta yang ditemukan menggunakan statistik. Hasil analisis statistik deskriptif dipaparkan dalam bentuk tabel, grafik, diagram lingkar dan pictogram (Idrus, 2009). Uji crosstab digunakan untuk menguji adanya hubungan yang signifikan atau tidak antara alih fungsi lahan terhadap luas kepemilikan lahan, alih pekerjaan dan persediaan pangan (Setyowati dan Setioko, 2013).

\section{HASIL DAN PEMBAHASAN}

\section{Kondisi Demografi berkaitan dengan Fungsi Lahan}

Penduduk kecamatan Sayung mengalami peningkatan selama 4 tahun terakhir antara 1,2-1,3\% (Tabel 1). Peningkatan jumlah penduduk menyebabkan terjadinya kepadatan penduduk. Empat desa terpadat di Kecamatan Sayung berturut-turut adalah Jetaksari, Kalisari, Karangasem dan Dombo. Peningkatan penduduk ini meningkatkan kebutuhan lahan untuk pemukiman dan fasilitas lainnya.

Tabel 1. Jumlah Penduduk di Kecamatan Sayung tahun 2012-2015

\begin{tabular}{lcc}
\hline \hline Tahun & $\begin{array}{c}\text { Jumlah } \\
\text { penduduk } \\
\text { (orang) }\end{array}$ & $\begin{array}{c}\text { Persentase } \\
\text { kenaikan } \\
(\%)\end{array}$ \\
\hline 2012 & 100.142 & 1,30 \\
2013 & 101.425 & 1,30 \\
2014 & 102.692 & 1,20 \\
2015 & 103.932 & 1,20 \\
Rata-rata & & 1,25 \\
\hline
\end{tabular}

Sumber: BPS Sayung Dalam Angka 2016

Kepadatan penduduk dapat berdampak pada semakin terbatasnya sumber-sumber kebutuhan pokok seperti pangan dan papan yang layak untuk penduduk.Akibatnya sumber-sumber kebutuhan pokok tersebut tidak lagi sebanding dengan bertambahnya jumlah penduduk, yang dapat berakibat terhadap alih fungsi lahan pertanian. Mengakibatkan penurunan produksi padi dan jagung (Tabel 2).

Tabel 2. Jumlah Produksi Padi dan Jagung di Kecamatan Sayung Tahun 2012-2015

Produksi padi Produksi Jagung

Tahun Jumlah Penurunan Jumlah Penurunan

\begin{tabular}{rrrcc} 
& (ton) & (\%) & (ton) & (\%) \\
\hline 2013 & 21,4 & 10,80 & 5,5 & $31,3 \%$ \\
2014 & 17,4 & 18,70 & 4,7 & $14,5 \%$ \\
2015 & 17,0 & 2,30 & 3,5 & $25,5 \%$ \\
\hline
\end{tabular}

Sumber: BPS Sayung Dalam Angka 2015

Produksi padi sawah dan jagung Tahun 2013 - 2015 mengalami penurunan. Penurunan produksi padi rata-rata sebesar $10,6 \%$ dan Penurunan produksi jagung ratarata sebesar $23,8 \%$ dapat berpengaruh 
terhadap persediaan pangan yang menunjukkan tingkat ketahanan pangan.

\section{Pengajuan Perizinan Alih Fungsi Lahan di Kabupaten Demak Tahun 2014 -2015}

Kabupaten Demak terbagi menjadi 14 Kecamatan dan Kecamatan Sayung merupakan daerah yang mengalami peningkatan industri yang cukup besar. Tabel 3 menunjukkan penerbitan perijinan industri 3 tahun terakhir.

Tabel 3. Perizinan Industri di Kecamatan Sayung

\begin{tabular}{ccc}
\hline No & Tahun & Jumlah \\
\hline 1 & 2013 & 164 \\
2 & 2014 & 105 \\
3 & 2015 & 170 \\
\hline
\end{tabular}

Sumber : Badan Pelayanan Perizinan Terpadu dan Penanaman Modal, 2016

Tingginya alih fungsi lahan di Kabupaten Demak terlihat dari jumlah luas lahan yang termuat dalam pengajuan alih fungsi lahan di Kantor Badan Pertanahan Nasional (Ilustrasi1). Ilustrasi 1. menunjukkan bahwa penga-juan perizinan di bawah 1 ha di peruntukkan bagi rumah dan usaha skala mikro.Badan Pertanahan Nasional mengatur perizinan untuk tempat tinggal tidak boleh

lebih dari $500 \mathrm{~m}^{2}$ dan perizinan diatas 1 ha untuk perusahaan dan usaha skala besar.Petugas BPN menjelaskan bahwa tidak semua pengajuan perizinan alih fungsi lahan diterima, hal itu disebabkan ada peraturan mengenai tata letak lahan dan peruntukannya. Perubahan fungsi lahan di Kecamatan Sayung ini tidak berbeda jauh dari penelitian Witjaksono et al., (2015) di Provinsi Jawa Timur yang mendapatkan bahwa faktor yang dapat mempengaruhi alih fungsi lahan pertanian ke lahan nonpertanian yaitu kepadatan penduduk, pertumbuhan industri dan sektor nonpertanian, perkembangan wilayahdan perubahan sosial masyarakat.

Perubahan Luas Lahan Petanian di Kecamatan Sayung Tahun 2012 - 2015

Tingginya perizinan alih fungsi lahan pertanian di Kabupaten Demak mengakibatkan perubahan luasan lahan pertanian di semua kecamatan. Luas lahan pertanian di Kecamatan Sayung tahun 2012-2015 mengalami penurunan yang cukup tinggi dari 2.136 ha menjadi 1.417 ha dengan persentase rata - rata penurunannya sebesar $12,4 \%$ (Ilustrasi 2).

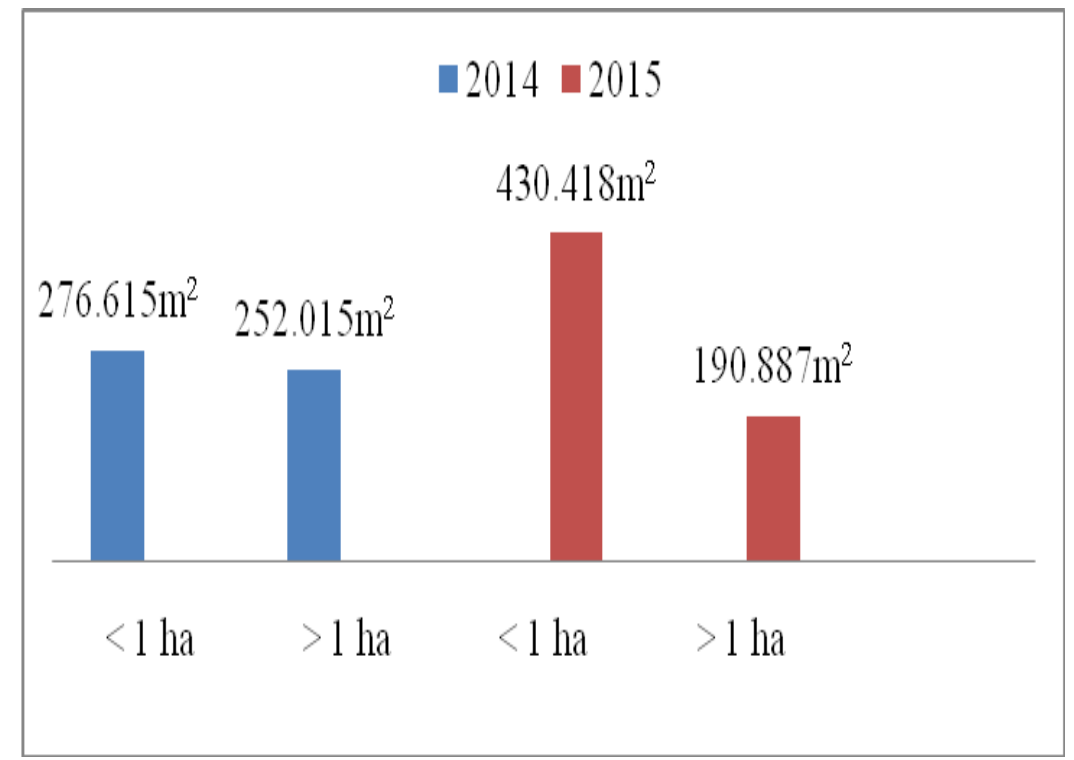

Ilustrasi 1. Diagaram Batang Luas Lahan menurut Pengajuan Perizinan Alih Fungsi Lahan Di Kabupaten Demak Tahun 2014-2015

Sumber data : Badan Pertanahan Nasional 2014 - 2015 


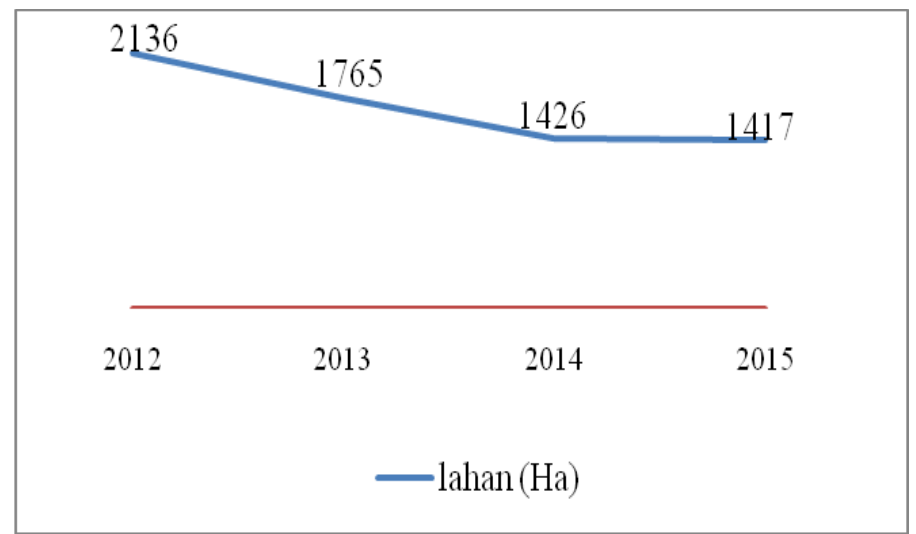

Ilustrasi 2. Grafik Penurunan Luas Lahan Pertanian di Kecamatan Sayung Tahun 2012 - 2015

Sumber : Dinas Pertanian Kabupaten Demak

Ilustrasi 2 menunjukkan faktor utama yang berkontribusi dalam penurunan lahan pertanian adalah laju pertumbuhan penduduk yang menyebabkan meningkatnya kebutuhan untuk pemukiman dan fasilitas lainnya.Laju pertumbuhan penduduk ini bukan saja pertumbuhan alami, tetapi karena perpindahan penduduk sebagai akibat letak Kecamatan Sayung yang berdekatan dengan sentra industri di Kota Semarang. Penelitian Irawan (2005) menemukan bahwa di Indonesia yang mempengaruhi alih fungsi lahan adalah peningkatan jumlah penduduk yang memicu pembangunan kawasan perumahan dan berkembangnya industri.

\section{Jenis Alih Fungsi Lahan Pertanian}

Proses pelepasan mengakibatkan perubahan fungsi lahan pertanian ke fungsi lainnya seperti rumah, usaha dan kapling.

Ilustrasi 3 menunjukkan penurunan jum- lah responden yang memiliki lahan pertanian baik sawah maupun tegalan. Jumlah responden yang memiliki sawah pada awalnya 38 orang menurun menjadi 29 pada saat penelitian, sedangkan yang memiliki lahan tegalan dari 42 menjadi 17 orang. Ilustrasi 3 juga menerangkan bertambahnya responden yang memiliki lahan untuk nonpertanian (rumah, usaha dan kaplingan). Penelitian di Kecamatan Kudu Kabupaten Karangasem Bali oleh Saputra dan Budhi (2015) mendapatkan bahwa alih fungsi lahan merupakan perubahan lahan pertanian ke nonpertanian yang digunakan untuk memenuhi kebutuhan pemiliknya.

\section{Penyebab Alih Fungsi Lahan Pertanian}

Pelepasan lahan oleh responden disebabkan oleh beberapa alasan (Ilustrasi 4). Penyebab yang paling besar adalah untuk memenuhi kebutuhan ekonomi keluarga (41\%) berupa pembelian kebutuhan primer seperti pangan dan pakaian.

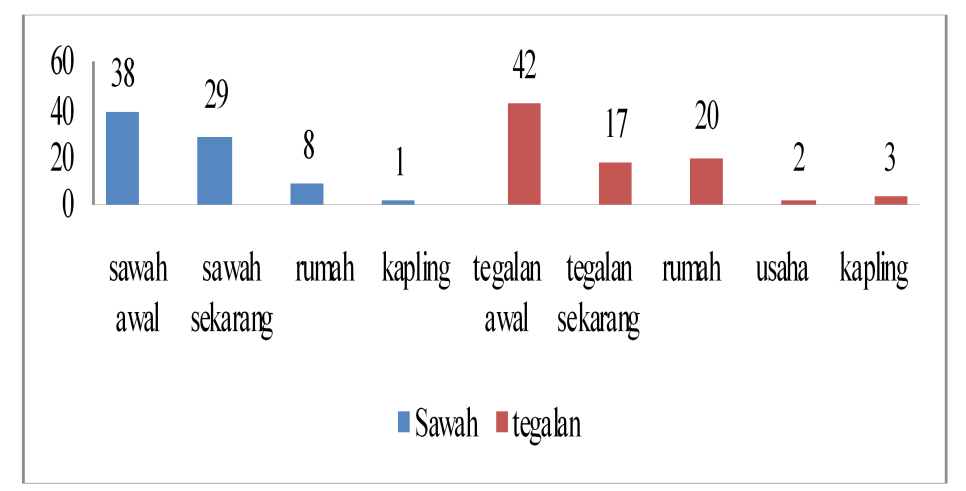

Ilustrasi 3. Diagram Batang Jumlah Responden menurut Jenis Lahan yang Dimiliki dan Perubahannya 


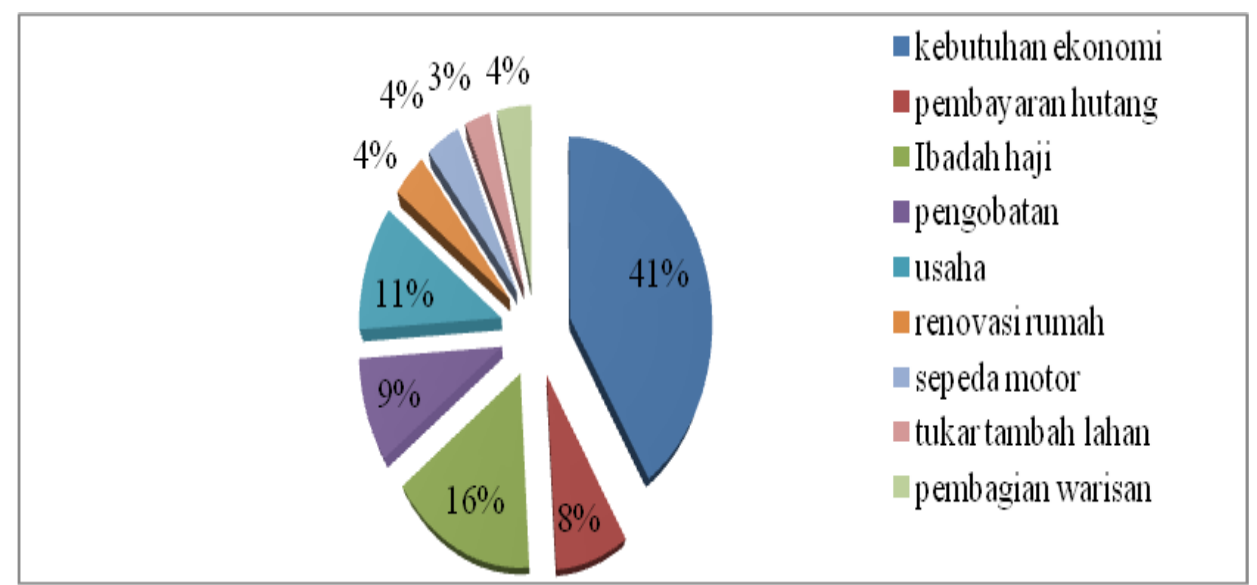

Ilustrasi 4. Diagram Pie Jumlah Responden Menurut Penyebab Alasan Penjualan Lahan Pertanian

Ilustrasi 4 menunjukkan bahwa penyebab lain yang cukup besar adalah untuk ibadah haji, usaha bisnis, pengobatan dan pembayaran hutang. Penelitian di wilayah pedesaan Indonesia, Winarso (2012) mendapatkan bahwa ada beberapa proses yang mengakibatkan alih fungsi lahan diantaranya dapat saja terjadi karena adanya transaksi jual beli, hibah atau transaksi lainnya seperti bagi hasil dan transaksi pembagian waris. Hal tersebut hampir sama dengan penelitian, Rohmadiani (2011) yang melaporkan bahwa di Jalan Pantura Kecamatan Pamanukan Kabupaten Subang. Faktor-faktor yang mendorong perubahan fungsi lahan adalah ekonomi, demografi dan budaya.

\section{Dampak Alih Fungsi Lahan Terhadap Luas Kepemilikan Lahan Pertanian}

Pelepasan lahan yang dilakukan oleh responden mengakibatkan dampak terhadap struktur kepemilikan lahan. Ilustrasi 5 menunjukkan perubahan struktur kepemilikan lahan pertanian responden. Sesuai dengan kriteria pemilihan responden, seluruh responden pada awalnya memiliki lahan pertanian yang berupa sawah atau tegalan dengan luasan yang berbeda-beda. Setelah pelepasan lahan ternyata 68 dari 80 resonden (85\%) menjadi tidak mempunyai lahan lagi. Kondisi ini mempunyai kesesuaian dengan penelitian Rohmadiani (2011) di Jalur Pantura Kecamatan Pamanukan Kabupaten Subang yang mendapatkan bahwa setelah pelepasan lahan $84,8 \%$ responden tidak mempunyai lahan pertanian lagi. Ilustrasi 5 bila dirinci menurut luasan lahannya, perubahan terutama

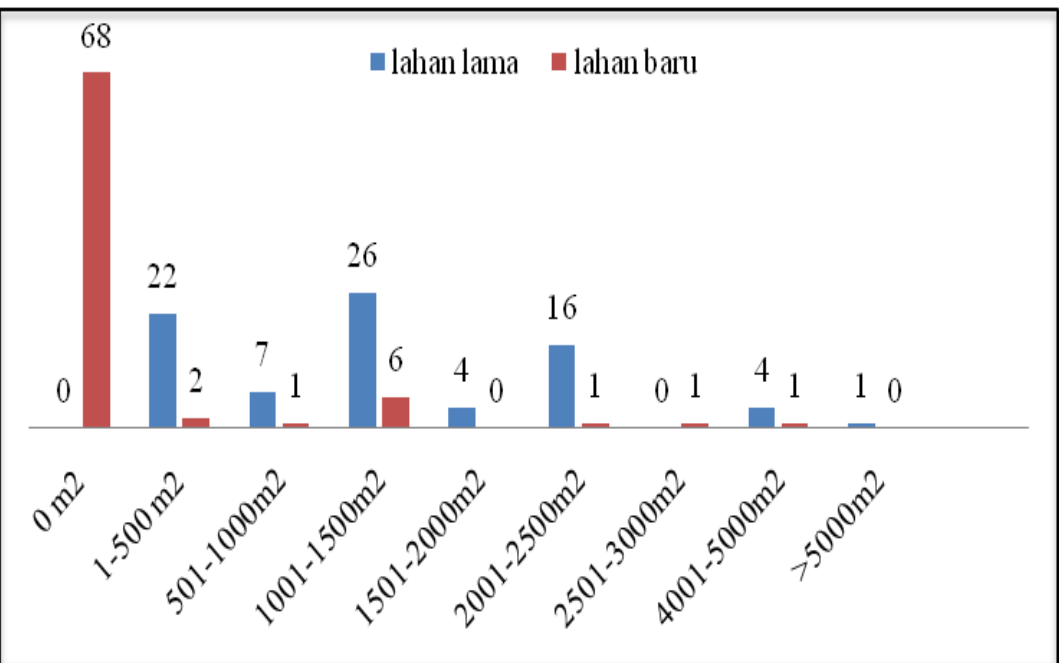

Ilustrasi 5. Diagram Batang Jumlah Responden berdasarkan Perubahan Kepemilikan Lahan Sebelum dan Sesudah Penjualan 
terjadi pada kepemilikan lahan $500 \mathrm{~m}^{2}$ ke bawah yang semula berjumlah 22 responden menurun tajam hingga hanya menjadi 2 orang. Kepemilikan 2001-2500 $\mathrm{m}^{2}$ semula 16 orang turun menjadi 1 orang. Saat penelitian tidak ada lagi responden yang memiliki lahan di atas $5000 \mathrm{~m}^{2}$. Penelitian di Bali oleh Santoso et al. (2011) mendapatkan bahwa alih fungsi lahan yang diawali dengan penjualan berpengaruh terhadap luasan kepemilikan lahan yang pada gilirannya berakibat terhadap penurunan pendapatan petani sehingga tidak mencukupi kebutuhan keluarga untuk hidup. Signifikansi dampak alih fungsi lahan terhadap luas kepemilikan lahanyang di ukur dengan crosstab dapat dilihat pada Tabel 4.

Berdasarkan hasil nonparamatik tests dengan uji tabulasi silang (crosstab) menunjukkan alih fungsi lahan terhadap luas kepemilikan lahan mempunyai hubungan sangat signifikan, nilai sig $0,00(p<0,01)$. Hal ini dapat diartikan bahwa alih fungsi lahan mempunyai dampak terhadap luas kepemilikan lahan petani.

\section{Dampak Alih Fungsi Lahan Terhadap Perubahan Pekerjaan}

Hasil penelitian ini menunjukkan bahwa penguasaan lahan pertanian sangat jauh menurun selama 10 tahun terakhir, bahkan $85 \%$ responden sudah tidak memiliki lagi.Hal ini berdampak pada jenis pekerjaan yang ditekuni (Ilustrasi 6 dan Tabel 5). Kebutuhan rumahtangga menuntut untuk beralih pekerjaan agar tetap ada pemasukan pendapatan. Pada ilustrasi tersebut bahkan ada 10 orang (12,5\%) yang berhenti sebagai petani dan tidak mempunyai kegiatan ekonomi lagi. Walaupun mereka kebanyakan beralasan karena umur sudah menua, yang jelas mereka sudah tidak memiliki lahan lagi.

Hasil tes nonparamatik alih fungsi lahan terhadap alih pekerjaan dengan crosstab

Tabel 4. Hasil Crosstab Alih Fungsi Lahan terhadap Luas Kepemilikan Lahan Responden

Crosstab

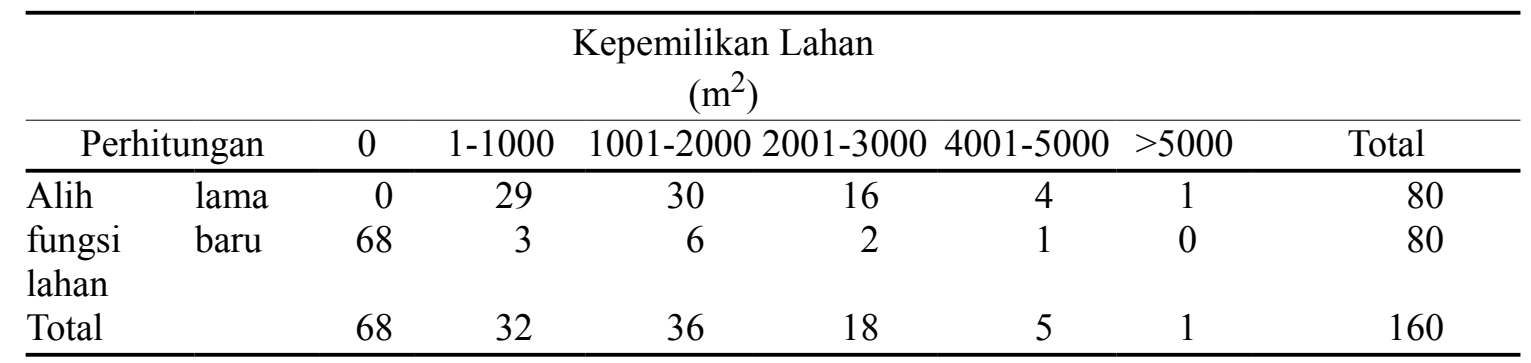

Sumber : Hasil pengolahan data primer.

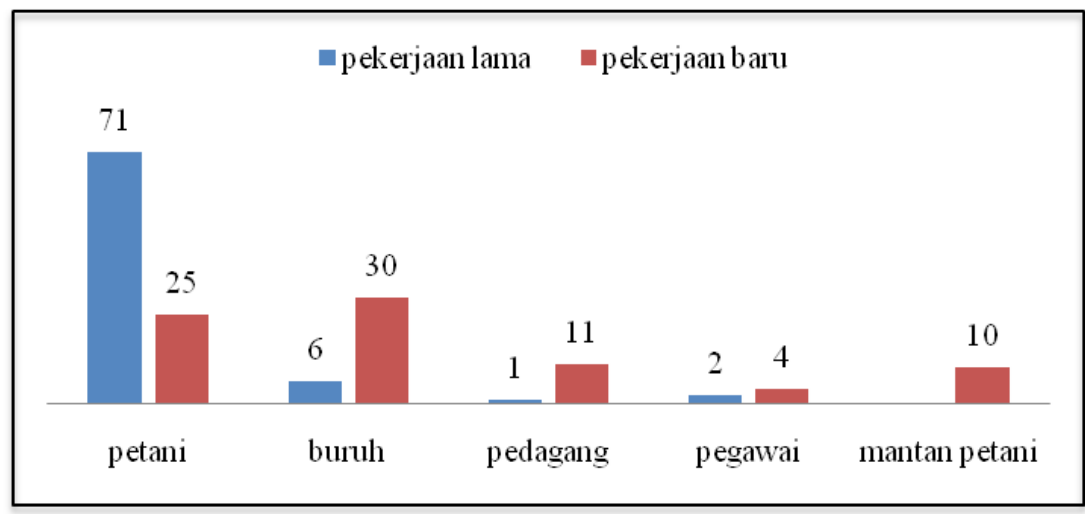

Ilustrasi 6.Diagram Batang Jumlah Responden berdasarkan Perubahan Pekerjaan Sesudah dan Sebelum Penjualan 
Tabel 5. Hasil Crosstab Alih Fungsi Lahan Terhadap Alih Pekerjaan

\begin{tabular}{lcrccccc}
\hline \hline \multicolumn{1}{c}{ count } & & Petani & Buruh & Pedagang & pegawai & Pensiunan & Total \\
\hline Alih & lama & 71 & 6 & 1 & 2 & 0 & 80 \\
fungsi & baru & 25 & 30 & 11 & 4 & 10 & 80 \\
lahan & & & & & & & \\
Total & 96 & 36 & 12 & 6 & 10 & 160 \\
\hline
\end{tabular}

Sumber : Hasil pengolahan data primer

menunjukkan hubungan sangat signifikan (sig 0,00). Ini dapat diartikan bahwa alih fungsi lahan mempunyai dampak terhadap alih pekerjaan petani. Hasil temuan ini selaras dengan temuan Rohmadiani (2011) di jalur pantura Kecamatan Pamanukan Kabupaten Subang. Penduduk yang semula bertani beralih pekerjaan menjadi buruh pabrik dan buruh bangunan, atau menjadi petani gurem dan buruh tani.

Ilustrasi 6 menunjukkan terjadinya perubahan struktur pekerjaan. Pada awalnya 71 dari 80 responden mempunyai pekerjaan utama sebagai petani, saat ini hanya tinggal 25 orang yang masih bertahan di pertanian. Sebaliknya, responden yang semula menjadi buruh hanya 6 orang meningkat menjadi 30 orang, dan pedagang yang semula hanya 1 orang meningkat menjadi 11 orang.

Perubahan struktur pekerjaan juga ditemukan dalam studi kasus Mawardi (2006) di Jawa Tengah. Para petani beralih ke pekerjaan sektor informal dan sulit untuk masuk ke sektor industri dan jasa karena mereka tidak mempunyai ketrampilan.Hal ini dapat disimpulkan alih fungsi lahan pertanian di pedesaan berakibat menambah kemiskinan baru di pedesaan.

\section{Dampak Alih Fungsi Lahan Pertanian Terhadap Persediaan Pangan Dalam Keluarga}

Pada awalnya semua responden memiliki persediaan pangan dalam keluarga yang berupa padi dari hasil pertanian dengan jumlah yang berbeda-beda. Penjualan lahan mengakibatkan persediaan pangan tersebut bekurang bahkan tidak ada lagi. Dampak alih fungsi lahan terhadap persediaan pangan dalam keluarga dapat dilihat pada Ilustrasi 7 dan Tabel 6.

Ilustrasi 7 menunjukkan bahwa saat ini 67 dari 80 responden sudah tidak mempunyai persediaan pangan berupa gabah hasil panen lagi. Penelitian di Provinsi Jawa Timur Witjaksono et al. (2015) mendapatkan bahwa alih fungsi lahan mengakibatkan pengurangan volume produksi gabah kering.

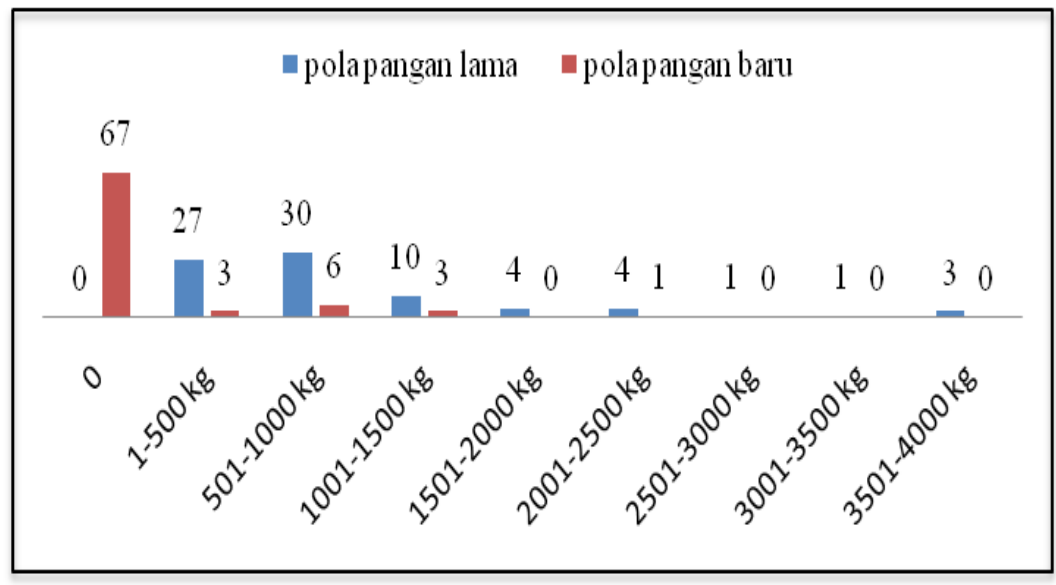

Ilustrasi 7. Digram Batang Jumlah Responden berdasarkan Perubahan Persediaan Pangan dalam Keluarga Sebelum dan Sesudah Penjualan 
Tabel 6. Hasil Crosstab Alih Fungsi Lahan terhadap Persediaan Pangan dalam Keluarga

\begin{tabular}{lccccccc}
\hline \hline \multicolumn{7}{c}{} & \multicolumn{7}{c}{ Persedian pangan $(\mathrm{kg})$} \\
\hline \multicolumn{2}{c}{ Perhitungan } & 0 & $1-1000$ & $1001-2000$ & $2000-3000$ & $3001-4000$ & Total \\
\hline $\begin{array}{l}\text { Alih } \\
\text { fungsi }\end{array}$ & lama & 0 & 57 & 14 & 5 & 4 & 80 \\
$\begin{array}{l}\text { lahan } \\
\text { Total }\end{array}$ & 67 & 9 & 3 & 1 & 0 & 80 \\
\hline
\end{tabular}

Sumber : Hasil pengolahan data primer.

Hasil uji tabulasi silang tersebut menunjukkan bahwa alih fungsi lahan mempunyai pengaruh yang sangat signifikan (sig. 0,00) terhadap persediaan pangan bagi petani. Temuan inis esuai dengan penelitian Mawardi (2006) di Jawa Tengah yang mendapatkan bahwa produksi padi di Jawa Tengah mengalami penurunan yang dikarenakan oleh alih fungsi lahan dari lahan pertanian yang disebabkan oleh perkembangan sektor industri yang sangat pesat di Pulau Jawa.

\section{SIMPULAN DAN SARAN}

\section{Simpulan}

Kabupaten Demak setiap tahun menerima pengajuan perizinan alih fungsi lahan yang cukup intensif.Luasan lahan pertanian yang beralih fungsi lahandi Kecamatan Sayung dari 2.136 ha menjadi 1.417 ha. Faktor - faktor yang mempengaruhi alih fungsi lahan pertanian di Kecamatan Sayung berturut-turut adalah kebutuhan ekonomi (41\%), ibadah haji (16\%), usaha $(11 \%)$, pengobatan $(9 \%)$, pembayaran hutang $(8 \%)$, renovasi rumah $(4 \%)$, pembelian motor (4\%), pembagian warisan $(4 \%)$ dan tukar tambah lahan (3\%). Alih fungsi lahan sangat signifikan mempengaruhi jumlah penduduk yang mempunyai lahan pertanian, luas kepemilikan lahan, alih pekerjaan dan persediaan pangan keluarga.

\section{Saran}

Berdasarkan hasil penelitian disarankan agar pemerintah menegaskan segala aturan mengenai alih fungsi lahan yang telah ada dan penegasan sanksi. Pemerintah harus membuat kebijakan dalam mengatasi alih fungsi alih lahan yang telah terjadi serta mengadakan penyuluhan mengenai pentingnya menjaga lahan pertanian agar tidak beralih fungsi kepada masyarakat.

\section{DAFTAR PUSTAKA}

Badan Pelayanan Perizinan Terpadu dan Penanaman Modal. 2013. Pemetaan Perizinan Tahun 2013 - 2015. BPPTPM Demak.

BPS Demak. 2015. Kecamatan Sayung Dalam Angka. BPS Demak.

BPN Demak. 2015. Jumlah Perizinan Alih Fungai Lahan. BPN Demak.

Dinas Pertanian Kabupaten Demak. 2015. Jumlah luasan lahan pertahun di Kabupaten Demak per Kecamatan. Dinas Pertanian Kabupaten Demak

Idrus, M. 2009. Metode Penelitian Ilmu Sosial.Yogyakarta. Pernerbit Erlangga. Universitas Islam Indonesia.

Irawan, B. 2005. Konversi lahan sawah: potensi dampak, pola pemanfaatannya, dan faktor determinan. Forum Penelitian Agro Ekonomi.23 (1): 1 - 18.

Mawardi, I. 2006. Kajian pembentukan kelembagaan untuk pengendalian konversi dan pengembangan lahan, peran dan fungsinya. Jurnal Teknik Lingkungan. 7 (2) : $206-2011$.

Nawawi, H. 2012. Metode Penelitian Bidang Sosial. Gajah Mada Universty Press. Yogyakarta.

Rohmadiani, L. D. 2011. Dampak konversi lahan pertanian terhadapekonomi petani. Jurnal Teknik.9 (2): 74 - 84.

Santoso, I. G. N., G. M. Adyana dan I. K. K. Dinanta. 2011. Dampak alih fungsi lahan sawah terhadap ketahanan pangan beras. 
Prosiding Seminar Nasional Budidaya Pertanian Pengendalian Alih Fungsi Lahan Pertanian.Urgensi dan Strategi.Bengkulu 7 Juli. 2011.

Saputra, I. G. W. S. dan M. K. Budhi. 2015. Studi alih fungsi lahan dan dampaknya terhadap sosial ekonomi pertanian jambu mete di Kecamatan Kudu, Kabupaten Karangasem. Jurnal Ekonomi dan Bisnis. 4.08 (2015): 555 - 570.

Setyowati, E. dan B. Setioko. 2013. Metode Riset dan Statistika. UPT UNDIP Press.
Semarang.

Winarso, B. 2012.Dinamika pola penguasaan lahan sawah di wilayah pedesaan di Indonesia.Jurnal Penelitian Pertanian Terapan. 12 (3): 137 - 149.

Witjaksono, A., Kustamar dan D. K. Sunaryo. 2015. Identifikasi perubahan lahan pertanian sebagai pertimbangan menyusun kebijakan lahan pertanian berkelanjutan. Prosiding Seminar Nasional Teknik Sipil V (2015). UMS. p194 - 199. 